\title{
On the origin and diversity of Newcastle disease virus in Tanzania
}

\author{
Authors: \\ Mmeta G. Yongolo ${ }^{1}$ \\ Henrik Christensen ${ }^{2}$ \\ Kurt Handberg ${ }^{3}$ \\ Uswege Minga ${ }^{4}$ \\ John E. Olsen ${ }^{2}$ \\ Affiliations: \\ ${ }^{1}$ Department of Virology, \\ Ministry of Livestock \\ Development, Tanzania \\ ${ }^{2}$ Department of Veterinary \\ Disease Biology, University of \\ Copenhagen, Denmark \\ ${ }^{3}$ Department of Clinical \\ Microbiology, University \\ Hospital of Aarhus, Denmark \\ ${ }^{4}$ Faculty of Science, \\ Technology and \\ Environmental Studies, \\ Open University of Tanzania, \\ Tanzania
}

\section{Correspondence to:} Henrik Christensen

Email:

hech@life.ku.dk

\section{Postal address:}

Department of Veterinary Disease Biology, University of Copenhagen, Stigbøjlen 4, 1870 Frederksberg C, Denmark

Dates:

Received: 20 Dec. 2010 Accepted: 08 Apr. 2011 Published: 30 Sept. 2011

How to cite this article: Yongolo, M.G., Christensen, H., Handberg, K., Minga, U. \& Olsen, J.E., 2011, 'On the origin and diversity of Newcastle disease virus in Tanzania', Onderstepoort Journal of Veterinary Research 78(1), Art. \#312, 8 pages. doi:10.4102/ojvr. v78i1.312

C) 2011. The Authors. Licensee: AOSIS OpenJournals. This work is licensed under the Creative Commons Attribution License.
Free-range rural chickens (FRCs) dominate the poultry industry in developing countries and chickens are exposed to multi-host infections, including Newcastle disease virus (NDV). The knowledge about the characteristics of NDV from FRCs is limited. This study investigated the persistence, spread and risks of NDV from FRCs. NDV isolates $(n=21)$ from unvaccinated FRCs in Tanzania were characterised by conventional intracerebral pathogenicity index (ICPI) and sequence analysis of a partial region of the deduced fusion protein encompassing the cleavage site. Results showed that five isolates were screened as lentogenic, nine as mesogenic and six as velogenic. Phylogenetic analysis of the 21 isolates compared to reference sequences revealed three, four, nine and five isolates in genotypes 1, 2, 3c and 4a, respectively. Genotype $3 \mathrm{c}$ also included published sequences of Tanzanian isolates obtained from exotic birds and chicken isolates from Uganda. The analysis showed that NDV were persistently present among chicken populations and possibly spread through live chicken markets or migration of wild birds. Differences in amino acid sequences detected around the cleavage site separated the isolates in six types. However, cleavage site pattern could not fully differentiate mesogenic isolates from velogenic isolates.

\section{Introduction}

Free-range rural chickens (FRCs) populations dominate the poultry industry in developing countries (Permin \& Hansen 1998; Regmi 2001). The management of FRC allows interactions between chickens and ducks, pigeons, wild birds and other animals. This predisposes chickens to multi-host infections, including Newcastle disease virus (NDV). Moreover, FRC flocks and populations are composed of multi-age chickens, which are usually not vaccinated. Over 250 species of birds are reported to be susceptible to NDV infection (Alexander 2001). Chickens are the most susceptible species and infections of susceptible birds with virulent NDV isolates lead to severe disease and heavy stock losses (Alexander 2001). Thus, Newcastle disease (ND) is apparently responsible for major losses in FRC populations (Spradbrow 1993). It is also of economical importance in commercial poultry production and trade worldwide (Alexander 2001). Major outbreaks have been reported since ND was reported for the first time (Lomniczi et al. 1998). Newcastle disease occurs sporadically among FRCs, with seasonal epidemics and up to $100 \%$ mortality in unvaccinated flocks (Spradbrow 2000; Yongolo, Machangu \& Minga 2002). Whereas much has been reported on NDV contributing to outbreaks in commercial production, knowledge is limited about the NDV circulating and causing ND oubreaks in FRC populations.

NDV are categorised as avian paramyxovirus serotype 1 (APMV-1) and belongs to the genus Avulavirus, subfamily Paramyxovirinae in the family Paramyxoviridae (eds. Van Regenmortel et al. 2000). The APMV-1 serotype has a negative-sense, single-stranded RNA genome composed of six genes coding for RNA-directed RNA polymerase, haemagglutinin-neuraminidase protein, fusion protein $(\mathrm{F})$, matrix protein, phosphoprotein and nucleoprotein (Philips, Samson \& Emmerson 1998). Fusion protein synthesised as a precursor $\mathrm{F}_{0}$ must be proteolytically cleaved to the peptides $\mathrm{F}_{1}$ and $\mathrm{F}_{2}$ for fusion activity to occur between virus and host. This separation occurs between amino acid residues 116 and 117, with postion 117 being the first amino acid for the $F_{1}$ fusion polypeptide. The sequence ${ }^{111} \mathrm{GGRQGR} / \mathrm{L}^{117}$ of an avirulent isolate turned virulent when converted to ${ }^{111}$ GRRQRRIF ${ }^{117}$ (Peeters et al. 1999) and the peptide sequence at the cleavage site can be used to predict virulence.

Virulence of NDV is conventionally estimated by determining the intracerebral pathogenicity index (ICPI), intravenous pathogenicity index and the mean death time in day-old chicks, 6-weekold chicks and embryonated chicken eggs (ECEs) of between 9 and 11 days old, respectively (Office International des Epizooties 2009). Results from these three methods cannot differentiate between strains and used alone they have very little epidemiological significance. Pathotyping by such methods can only classify NDV a highly (velogenic), moderately (mesogenic) and slightly (lentogenic) pathogenic. However, strain differentiation and epidemiological data can 
be achieved through restriction enzyme analysis, cleavage site mapping and sequence analysis of the fusion protein gene (Ballagi-Pordány et al. 1996). Based on these methods, eight genotypes have been revealed to have been involved in major epidemics (Yu et al. 2001). The genotypes have recently been reclassified and 16 new genotypes are now recognised (Aldous et al. 2003). Of the recent genotypes, novel genotypes VIIb, VIId and VIII (5b, 5d and 3d according to Aldous et al. 2003) were identified from outbreaks in southern Africa, Asia and Europe (Abolnik et al. 2004; Herczeg et al. 1999; Li et al. 2001; Lomniczi et al. 1998; Yang et al. 1999).

In this study, $21 \mathrm{NDV}$ isolates from Tanzanian FRCs and ducks, with no history of vaccination against ND (Yongolo 1996), were characterised to gain molecular epidemiological information. However, the characteristics of NDV affecting FRCs that could influence endemicity were not addressed or documented (Yongolo 1996). The aim of this study was to demonstrate NDV persistence, spread and infection FRC to further understanding of the epidemiology of ND in FRCs and possible risks to the commercial poultry industry.

\section{Materials and methods Materials}

The sources of virus are shown in Table 1. These isolates were samples taken from Tanzanian FRCs between 1994 and 1995 at monthly intervals. They were confirmed and deposited at the Central Veterinary Laboratories Agency, Weybridge, Surrey (UK) and deposited at the Sokoine University of Agriculture, Morogoro, Tanzania (Yongolo 1996). All isolates were passaged three times in ECEs (between 9 and 11 days old) before use. Of the 21 isolates, one had been isolated from live chicken markets in the Mbeya region of Tanzania and the rest from village chicken in the regions Morogoro and Tabora. One isolate was obtained from a duck kept with chickens in the same flock (Figure 1).

Before RNA extraction, all isolates were passaged in 10-day-old ECEs and the presence of NDV in the allantoic harvests was detected following standard procedures of haemagglutination (HA) and HA inhibition test according to the Commission of the European Communities (1992). The virulence of each isolate after the third passage was estimated by determining the ICPI in day-old chicks according to standards of the Office International des Epizooties (OIE 2009).

\section{Viral RNA extraction}

Viral RNA was extracted directly from the allantoic fluid harvested from NDV-infected ECEs. Virus extraction was performed at the Danish Veterinary Laboratory in Aarhus, Denmark. RNA was isolated using the QIAgen RNeasy Mini Kit RT-PCR system (QIAgen, Hilden, Germany) and Expand (Roche Diagnostics, Hvidovre, Denmark) according to the protocol provided with the QIAgen RNeasy ${ }^{\circledR}$ kit. Cells in $400 \mu \mathrm{L}$ of the allantoic fluid were lysed and DNase inactivated using $284 \mu \mathrm{L}$ RTL buffer that contained guanidine isothiocyanate (GITC), with subsequent addition of $6 \mu \mathrm{L}$ of

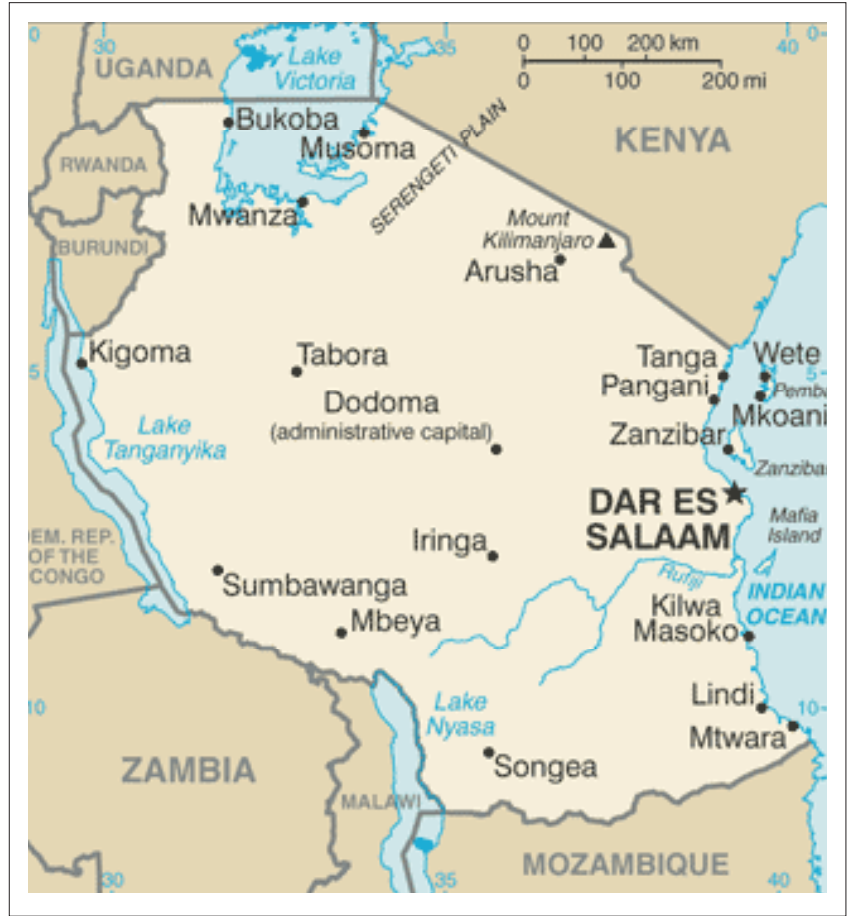

FIGURE 1: Map of Tanzania with indication of the three regions from where isolates were received.

$\beta$-mercaptoethanol. The spin column was washed using the two washing buffers, RW1 and RPE, provided in the kit and followed by centrifugation. Elution was performed with $50 \mu \mathrm{L}$ RNase-free water and the elute was preserved at $-20{ }^{\circ} \mathrm{C}$ until use.

\section{Primers and reverse transcriptase polymerase chain reaction}

Primer sequences, originally designed to amplify the $\mathrm{F}$ protein gene between position 148 and 535 to yield an expected product 388 nucleotides long, were obtained from Jørgensen et al. (1999). The procedure for single-tube reverse transcriptase polymerase chain reaction (RT-PCR) was carried out according to Jørgensen et al. (1999) using $\mathrm{MgCl}_{2}$ at a concentration of $1.5 \mathrm{mM}$. All reagents were handled on ice and the enzyme was added just before transferring the reagents to the PCR machine (PTC-200, MJ Research, Watertown, Massachusetts). Initial reverse transcription was performed for $30 \mathrm{~min}$ at $50{ }^{\circ} \mathrm{C}$ and denaturation was then carried out for $2 \mathrm{~min}$ at $94{ }^{\circ} \mathrm{C}$. Ten cycles, entailing denaturation for $30 \mathrm{~s}$ at $94{ }^{\circ} \mathrm{C}$, annealing for $30 \mathrm{~s}$ at $58{ }^{\circ} \mathrm{C}$ and elongation for $1 \mathrm{~min}$ at $68{ }^{\circ} \mathrm{C}$, were performed. After 10 cycles, an additional 25 were performed with the elongation time extended by $5 \mathrm{~s}$ in each cycle. Finally, elongation was performed for $7 \mathrm{~min}$ at $68^{\circ} \mathrm{C}$.

After RT-PCR, DNA was extracted from a sliced agarose gel (stained with ethidium bromide) using the QIAgen II Gel Extraction kit as described by the QIAEX II Handbook (QIAgen, Hilden, Germany). The elute was centrifuged and the DNA-containing supernatant was stored at $-20{ }^{\circ} \mathrm{C}$ until use. Sequencing of the RT-PCR-derived nucleotide sequences was determined by cycle sequencing (Sears et al. 1992), using the Amplitaq FS dye terminator kit and the 373A automatic 
sequencer (Applied Biosystems, Foster City, California). The primers NDV-2 and NDV-3 (Jørgensen et al. 1999) used during PCR amplification were also used in sequencing. The conditions for performing DNA sequencing and data evaluation were as recommended by Applied Biosystems.

\section{Sequence analysis, alignment and phylogenetic analysis}

Sequence analysis was performed on 17 isolates from FRCs and a duck. Sequences were compared to reference sequences from other parts of the world, selected to represent the 16 genotypes reported to date (Aldous et al. 2003). Further selection of sequences was based on the BLAST search programme (Altschul et al. 1997) in the GenBank database (Benson et al. 2004) in order to identify closely related sequences. Only sequences with clear indication of isolate identity, host and country of origin were included. Six sequences previously determined from Tanzanian isolates (Aldous et al. 2003; Seal et al. 1998) and all sequences described for the African continent were also included. The region of the F protein gene between position 231 and 374
(B1 isolate, accession number NC_002617) was aligned with representatives of published genotypes resulting in 180 positions for comparison. Pair-wise sequence comparisons were performed using EMBOSS (WATER) (http://www.ebi. ac.uk). The phylogenetic analysis was perfomed by neighbour joining analysis by ClustaxX (Thompson et al. 1997) and the tree visualised by MEGA4 (Tamura et al. 2007).

\section{Results}

Results from the virulence assessment in day-old chicks showed the ICPI to be between 0.0 and 2.0 (Table 1). ICPI intervals of $0.00-0.70,0.71-1.20$ and $1.21-2.00$ were used to classify the virus as lentogenic, mesogenic or velogenic, respectively.

The phylogenetic tree is shown in Figure 2. NDV isolates from Tanzania were asigned to four of the 16 genotypes defined earlier (Aldous et al. 2003). The three isolates classified as genotype 1 (Table 2 and Figure 2) showed 98.4$99.2 \%$ nucleotide similarity. Four isolates, including the only one from the Mbeya region and the reference strain B1, were

TABLE 1: List of Newcastle disease virus isolates investigated.

\begin{tabular}{|c|c|c|c|c|c|}
\hline Isolate & Time of isolation & Health status & ICPI & Virulence by ICPI & Partial F-gene sequences accession no. \\
\hline TB9.26C & Sep-95 & Healthy & 0.50 & $\mathrm{~L}$ & AY160155 \\
\hline MG6.11C & Jun-95 & Healthy & 0.78 & M & AY160131 \\
\hline MG7.10C & Jul-95 & Sick & 0.46 & L & AY160152 \\
\hline MG10.3C & Oct-95 & Healthy & 0.00 & L & AY160129 \\
\hline TB9.18C & Sep-95 & Healthy & ND & ND & FJ713136 \\
\hline MB9.38C & Sep-94 & Sick & 0.33 & L & AY160149b \\
\hline MG1.15C & Jan-95 & Healthy & 0.77 & M & AY160145 \\
\hline MG2.40C & Feb-95 & Healthy & 0.87 & M & AY160134 \\
\hline MG2.32C & Feb-95 & Sick & 0.98 & $M$ & AY160130 \\
\hline MG $4.8 \mathrm{C}$ & Apr-95 & Healthy & 1.08 & $M$ & AY175728 \\
\hline MG6.28C & Jun-95 & Sick & 1.58 & V & AY160141 \\
\hline MG6.33C & Jun-95 & Healthy & 0.95 & $M$ & AY160151 \\
\hline MG10.4C & Oct-95 & Sick & 1.67 & V & AY175653 \\
\hline MG10.5C & Oct-95 & Sick & 1.58 & v & AY160139 \\
\hline TB1.34C & Jan-95 & Healthy & 1.25 & $M$ & AY160137 \\
\hline TB2.24D & Feb-95 & Healthy & 0.95 & $M$ & AY175656 \\
\hline TB2.13C & Feb-95 & Healthy & 0.50 & L & AY175655 \\
\hline MG3.35C & Mar-95 & Healthy & 1.95 & v & AY160140 \\
\hline MG6.9C & Jun-95 & Sick & 1.11 & $M$ & AY160142 \\
\hline MG6.16C & Jun-95 & Healthy & 1.56 & V & AY160135 \\
\hline MG6.30C & Jun-95 & Healthy & 2.00 & v & AY160154 \\
\hline \multicolumn{6}{|c|}{ References included for sequence comparison } \\
\hline B1 & $\mathrm{NI}$ & - & - & - & NC_002617 \\
\hline NX4 & 2006 & - & - & - & FJ480817 \\
\hline $\mathrm{NI}$ & $\mathrm{NI}$ & - & - & - & Z12109 \\
\hline 17498 & 1998 & - & - & - & AY444501 \\
\hline 1168 & 1984 & - & - & - & AF109885 \\
\hline Taiwan95 & $\mathrm{NI}$ & - & - & - & U62620 \\
\hline 37821 & 1996 & - & - & - & AY288999 \\
\hline Largo & 1971 & - & - & - & AY288987 \\
\hline 6324 & 1995 & - & - & - & AF015519 \\
\hline
\end{tabular}

C, chicken; D, duck; ICPI, intracerebral pathogenecity index; MB, Mbeya; MG, Morogoro; ND, not done; NI, no information; TB, Tabora.

Please see the full reference list of the article, Yongolo, M.G., Christensen, H., Handberg, K., Minga, U. \& Olse, J.E., 2011, 'On the origin and diversity of Newcastle disease virus in Tanzania', Onderstepoort Journal of Veterinary Research 78(1), Art. \#312, 8 pages. doi:10.4102/ojvr.v78i1.312, for more information.

a, Published by Aldous et al. (2003).

b, Resequenced in 2009. 
described as belonging to genotype 2 (Table 2 and Figure 2). The isolates of this group investigated in the current study showed 97.4-99.6\% DNA sequence similarity. BLAST search showed nearly 100 sequences with high similarity to this genotype 2, including more versions of the LaSota strain (data not shown).

Nine isolates belonged to genotype 3c (Table 1 and Figure 2). The isolates showed $90.6-100 \%$ DNA sequence similarity. Isolates MG6.33C and TB1.34 even shared sequences, as did MG10.4C and MG10.5C (Table 2). The only duck isolate was included in this genotype. The Ugandan outbreak strain also belonged to this group and showed the highest similarity to isolate MG10.5C (97.9\%). The presence of identical sequences in different regions of Tanzania, as well as the high similarity to the strain from Uganda, indicates rapid spread of NDV. Isolate 6324/95 sampled in 1995 from wild birds represented in the investigation of Seal et al. (1998) also belonged to this group.

Five Tanzanian isolates were grouped as belonging to genotype 4a (Table 2 and Figure 2). The isolates showed

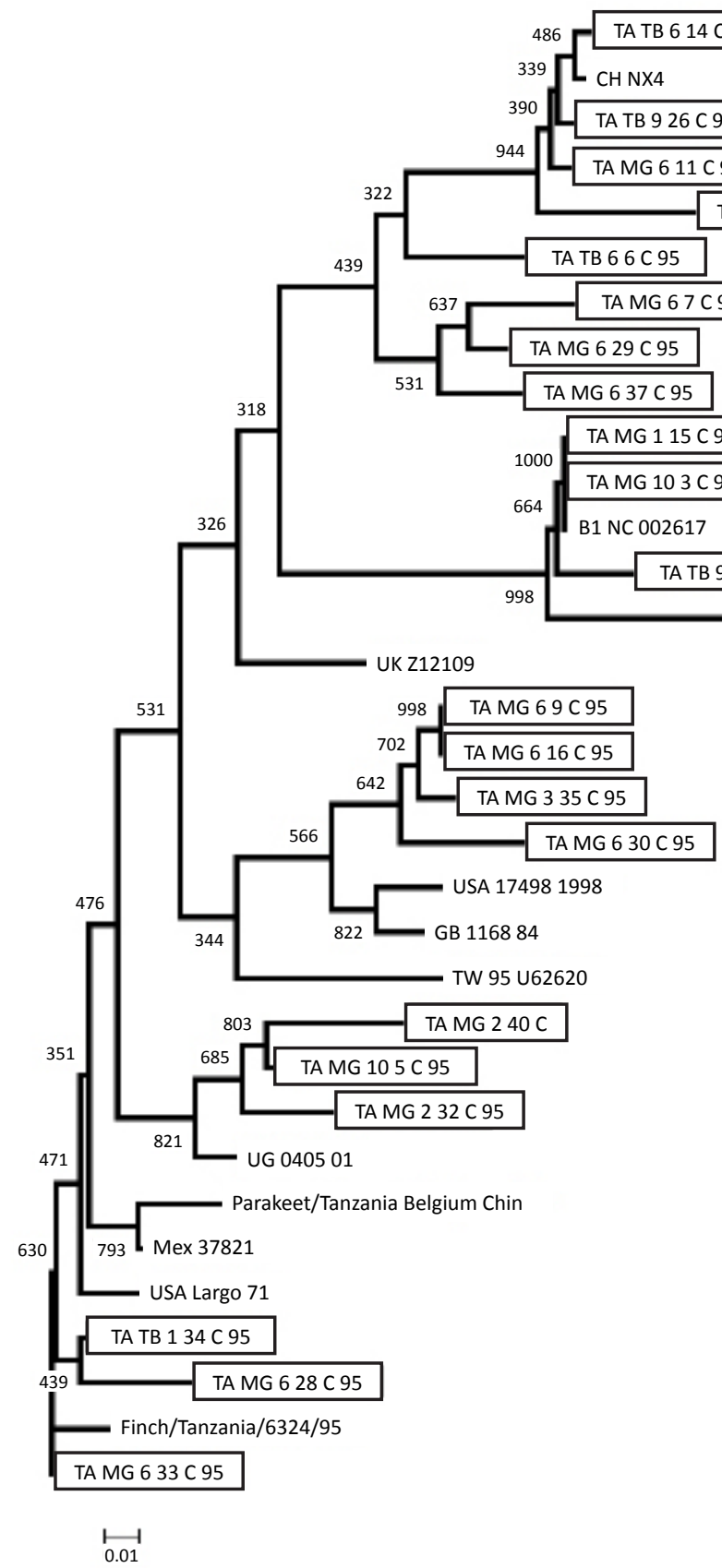

Genogroups are indicated with reference to Aldous, E.W., Mynn, J.K., Banks, J. \& Alexander, D.J., 2003, 'A molecular epidemiological study of avian paramyxovirus type 1 (Newcastle disease virus) isolates by phylogenetic analysis of a partial nucleotide sequence of the fusion protein gene', Avian Pathology 32, 239-256. doi:10.1080/030794503100009783, doi:10.1080/030794503100009731, PMid:12850913 with past genotype designation in brackets. The bar indicates nucleotide substitutions per position under consideration of Jukes \& Cantor substitution matrix. The numbers at branches are bootstrap percentages based on 1000 simulations.

FIGURE 2: Neighbour-joining-based phylogeny of Newcastle disease virus isolates from Tanzania with reference to published genotypes based on partial nucleotide sequence comparison of the $\mathrm{F}$ gene. 
96.6-99.0\% DNA sequence similarity. Isolate MG3.35C was isolated in March 1995, while MG6.9C, MG6.16C and MG6.30C were isolated in June 1995. MG3.35C may have been the progenitor NDV for the June isolates. This group showed only little similarity to other sequences deposited in the nucleotide databases $(<92 \%)$, as determined by the BLAST search.

The predicted amino acid sequences of the fusion protein gene region (positions 231-420) were aligned. The variations observed for the Tanzanian isolates are shown in Table 2. All isolates for genotypes 1 and 2 showed leucine at position 117 of the cleavage site, whereas genotypes $3 \mathrm{c}$ and 4 a sequences showed phenylalanine at that position.

\section{Discussion}

According to Aldous and Alexander (2001) NDV is an APMV-1 with an ICPI of 0.7 or higher or with at least three basic amino acids between positions 113 and 116 and phenylalanine at position 117. Most of the APMV-1 virus isolated in the present study fit this definition, except for three isolates (MG10.3C, MG7.10C, TB9.26C) with an ICPI of 0.5 or lower and leucine at position 117 (see Tables 1 and 2).

The NDV isolates from Tanzania could be classified as genotypes 1, 2, 3c and 4a according to the Aldous et al. (2003) designations. Genotype 2 viruses are known to be vaccine strains mainly isolated from the USA (Herczeg et al. 1999; Liang et al. 2002). The LaSota strain, which is the commonly used type of vaccine in Tanzania, could have been the progenitor virus for some of the isolates involved in disease.

The study showed that isolates belonging to genotype $3 \mathrm{c}$ were dominant and involved in ND outbreaks amongst FRCs in Tanzania and probably also other east African countries. The nine isolates were velogenic or mesogenic and isolated from apparently healthy or sick birds (Table 1). Otim et al. (2004) identified a member of genotype $3 c$ from ND outbreaks in Uganda, which may be related to those from Tanzania in the current investigation. This would confirm that poultry move between Uganda and Tanzania. However, other sources for these isolates may also exist, because Lomniczi et al. (1998) reported that old Hungarian isolates belong to this group. Members of this group have also been reported in the USA, Mexico (see Figure 2) and Germany, dating back to the 1970s (Wehmann et al. 2003). The isolates reported by Seal et al. (1998) from finch and parakeet also belonged to this group.

Unfortunately, Abolnik et al. (2004) sequenced another partial region than we did and sequences could therefore not be compared phylogenetically. Based on the comparison of labelled groups, group 3c (old V) was found in Tanzania but

TABLE 2: Protein signatures of the F gene cleavage site of Newcastle disease virus compared to published cleavage sites of slightly virulent and virulent Newcastle disease virus.

\begin{tabular}{|c|c|c|c|c|c|c|c|c|c|}
\hline \multirow[t]{4}{*}{ Isolate } & \multirow[t]{4}{*}{ Virulence prediction by ICPI } & \multirow[t]{4}{*}{ Genotype $^{c}$} & \multicolumn{7}{|c|}{ Protein sequence } \\
\hline & & & 1 & 1 & 1 & 1 & 1 & 1 & $1^{\mathrm{a}}$ \\
\hline & & & 1 & 1 & 1 & 1 & 1 & 1 & 1 \\
\hline & & & 1 & 2 & 3 & 4 & 5 & 6 & 7 \\
\hline MG6.11C & M & 1 & G & $\mathrm{R}$ & K & Q & G & $\mathrm{R}$ & $\mathrm{L}$ \\
\hline TB9.26C & $\mathrm{L}$ & 1 & G & G & K & Q & G & R & $\mathrm{L}$ \\
\hline MG7.10C & $\mathrm{L}$ & 1 & G & G & K & Q & G & R & $\mathrm{L}$ \\
\hline MB9.38C & L & 2 & G & G & $\mathrm{R}$ & Q & G & $\mathrm{R}$ & L \\
\hline MG10.3C, TB9.18C & L & 2 & G & G & $\mathrm{R}$ & Q & G & $\mathrm{R}$ & $\mathrm{L}$ \\
\hline MG1.15C & M & 2 & G & G & $\mathrm{R}$ & Q & G & $\mathrm{R}$ & $\mathrm{L}$ \\
\hline \multirow[t]{4}{*}{ Published data for low virulence ${ }^{b}$} & & & G & G & $\mathrm{R}$ & Q & G & $\mathrm{R}$ & $\mathrm{L}$ \\
\hline & & & & $\mathrm{R}$ & K & & $\mathrm{R}$ & & \\
\hline & & & & $\mathrm{E}$ & & & $\mathrm{K}$ & & \\
\hline & & & & & & & $\mathrm{E}$ & & \\
\hline MG3.35C & $\mathrm{V}$ & $4 a$ & G & $\mathrm{R}$ & $\mathrm{R}$ & Q & $\mathrm{K}$ & $\mathrm{R}$ & $\mathrm{F}$ \\
\hline MG6.30C & V & $4 a$ & $\mathrm{R}$ & $\mathrm{R}$ & $\mathrm{R}$ & Q & $\mathrm{R}$ & $\mathrm{R}$ & $\mathrm{F}$ \\
\hline MG6.16C & V & $4 a$ & G & $\mathrm{R}$ & $\mathrm{R}$ & Q & $\mathrm{K}$ & $\mathrm{R}$ & $\mathrm{F}$ \\
\hline TB2.13C & L & $4 a$ & G & $\mathrm{R}$ & $\mathrm{R}$ & Q & $\mathrm{K}$ & $\mathrm{R}$ & $\mathrm{F}$ \\
\hline MG6.9C & M & $4 a$ & G & $\mathrm{R}$ & $\mathrm{R}$ & Q & $\mathrm{K}$ & $\mathrm{R}$ & $\mathrm{F}$ \\
\hline TB1.34C, MG6.33C, MG4.8C & M & $3 c$ & G & $\mathrm{R}$ & $\mathrm{R}$ & Q & $\mathrm{K}$ & $\mathrm{R}$ & $\mathrm{F}$ \\
\hline MG6.28C & $\mathrm{V}$ & $3 c$ & G & $\mathrm{R}$ & $\mathrm{R}$ & Q & $\mathrm{K}$ & $\mathrm{R}$ & $\mathrm{F}$ \\
\hline MG2.40C & M & $3 c$ & G & $\mathrm{R}$ & D & Q & E & $\mathrm{R}$ & $\mathrm{F}$ \\
\hline MG2.32C & M & $3 c$ & G & $\mathrm{R}$ & $\mathrm{R}$ & Q & $\mathrm{K}$ & $\mathrm{R}$ & $\mathrm{F}$ \\
\hline MG10.4C, MG10.5C & V & $3 c$ & G & $\mathrm{R}$ & $\mathrm{R}$ & Q & $\mathrm{K}$ & $\mathrm{R}$ & $\mathrm{F}$ \\
\hline TB2.24D & M & $3 c$ & G & $\mathrm{R}$ & $\mathrm{R}$ & Q & $\mathrm{K}$ & $\mathrm{R}$ & $\mathrm{F}$ \\
\hline \multirow[t]{4}{*}{ Published data for virulent ${ }^{b}$} & & & G & $\mathrm{R}$ & $\mathrm{R}$ & Q & $\mathrm{K}$ & $\mathrm{R}$ & $\mathrm{F}$ \\
\hline & & & v & K & K & $\mathrm{K}$ & $\mathrm{R}$ & & \\
\hline & & & S & G & & $\mathrm{R}$ & G & & \\
\hline & & & $\mathrm{P}$ & & & & & & \\
\hline
\end{tabular}

ICPI, intracerebral pathogenecity index; $\mathrm{M}$, mesogenic; L, lentogenic; $\mathrm{V}$, velogenic.

Please see the full reference list of the article, Yongolo, M.G., Christensen, H., Handberg, K., Minga, U. \& Olse, J.E., 2011, 'On the origin and diversity of Newcastle disease virus in Tanzania', Onderstepoort Journal of Veterinary Research 78(1), Art. \#312, 8 pages. doi:10.4102/ojvr.v78i1.312, for more information.

a, Vertical line (I) indicates cleavage site.

', Aldous and Alexander (2001); Gould et al. (2003); Herczeg et al. (1999); Jørgensen et al. (1999); Lomniczi et al. (1998); Oberdörfer and Werner (1998); Otim et al. (2004); Peeters et al. (1999); Seal et al. (1995, 1998); Snoeck et al. (2009); Westbury (2001); Wehmann et al. (2003).

c, Aldous et al. (2003). 
does seem to have been present in South Africa. Groups IV, VIIb, VIIc, VIId and VIII, in turn, were found in South Africa but not in Tanzania.

Five isolates belonged to genotype $4 \mathrm{a}$, of which three were velogenic. This genotype is not reported often. Isolates belonging to genotype $4 \mathrm{a}$ were only represented by 10 sequences in the work of Aldous et al. (2003) and one of these was the isolate TB2.13C also described in the present study. Five isolates were from countries in the Middle East and the United Arabic Emirates. In other reports, isolates of this genotype have been associated with older outbreaks of ND amongst hosts such as fowls, ostriches and pigeons in European and Asian countries (Lomniczi et al. 1998).

The presence of genotype 1 NDV was reported in Tanzania for the first time. It is apparent from this study that genotype 1 NDV are still prevalent. Members of genotype 1, together with those of genotypes 2, 3a and 3b (Aldous et al. 2003), have been reported to be involved in the first panzootic outbreaks (Herczeg et al. 1999; Yu et al. 2001). Because genotype 1 NDV were involved in the first panzootic outbreak, which started in the mid-1920s in other parts of the world, and the recovery of related NDV in Tanzania in 1995, old genotypes are possibly still circulating worldwide, together with new genotypes. It is well known from previous findings that genotype 1 viruses are mainly lentogenic (Collins, Bashiruddin \& Alexander 1993; Peeters et al. 1999; King \& Seal 1998). All three genotype 1 isolates had leucine at position 117, which is found only in low-virulence NDV (Collins, Govey \& Alexander 2003; Kant et al. 1997; Oberdörfer \& Werner 1998; Seal, King \& Bennett 1995), whereas all virulent NDV have phenylalanine at position 117 (Collins et al. 1993). Genotype 1 comprised representative isolates from the two sampled regions of Tanzania. It is not known when genotype 1 viruses could have been introduced into Tanzania. Isolate V4 could possibly have been introduced into Tanzania as a thermostable vaccine for research purposes in 1992, 1995 and 1996 (Foster et al. 1999). Given the geographical location and the short time since V4 was introduced in Tanzania it is most unlikely that it is the progenitor virus for this group. On the other hand, V4 may have spread from neighbouring Malawi, where extensive field trials using the thermostable V4 had been carried out to control ND in intensive and smallholder village chicken flocks before 1987 (Sagild \& Haresnape 1987).

The absence of genotypes 5a, 5b, 5c, 5d, 3d (Aldous et al. 2003) viruses in Tanzania indicates that NDV, which caused devastating outbreaks of velogenic ND from 1993 to 1995 in southern African countries, did not reach Tanzania or were not isolated (Herczeg et al. 1999). Recent outbreaks from Nigeria were found to belong to genotypes $5 \mathrm{f} / \mathrm{g} / \mathrm{h}$ and $3 \mathrm{a}$ in addition to 1 and 2 (Snoeck et al. 2009); however, members of these groups were not identified from Tanzania. We can conclude that no particular unique types of NDV exist in Tanzania, but that the current types observed probably have descended from past outbreak strains in other parts of the world as well as from vaccine strains.
No temporal correlation was found between isolates sampled in Morogoro, Tabora or Mbeya. At Morogoro and Tabora all four genotypes were sampled; however, most isolates were obtained from Morogoro in June 1995 and they belonged to three genotypes (1,3c and $4 \mathrm{a})$. The study has shown that NDV is endemic to Tanzania, because NDV was isolated from village and markets in different geographical locations at different times of the year. Our study also showed that the different isolates from the chickens and ducks showed different levels of virulence and that multiple lineages were circulating amongst domestic birds. This is important because such birds could be the source of potentially virulent NDV to FRCs and commercial poultry worldwide. The presence of different pathotypes was confirmed by ICPI and the presence of variable amino acid sequences at the cleavage site. The presence of variable pathotypes in the field may complicate disease outcome and diagnosis. Therefore, mere isolation of NDV cannot be used for ND diagnosis or for determining the prevalence of ND unless characterisation and clinical disease are correlated. The persistent presense of NDV in FRCs is important because they predispose chickens to secondary and opportunistic upper respiratory bacterial infections (such as from Escherichia coli). Therefore, frequent programmed vaccination is recommended. This will guarantee protection of most chickens in an endemic situation. Enforcement of biosecurity may be the best alternative, but this is not feasible in the free-range system with its low input and low output management system, as is commonly practiced in Tanzania and other developing countries.

Genetic variations amongst NDV in FRCs were established in this study. These results showed an epidemiological relationship between NDV from FRCs of Tanzania to NDV reported in other countries. Accorrding to Tsai et al. (2000), viral divergence of $0.2-0.9 \%$ indicates that the viruses are genetically highly homogenous and similar. In the present study, more than $99 \%$ similarity was found amongst some members of all genotypes and even between isolates from different regions (Morogoro and Tabora). DNA similarity of up to $100 \%$ amongst some isolates found in the two regions studied and the phylogenetic tree analysis provided evidence that the isolates had a common origin. However, results in this study showed that no group of viruses was found exclusively in Tabora, although a specific group of viruses was found only in Morogoro. Isolates from Tabora may therefore have had the same ancestor as some of the Morogoro isolates. The one-way type of relationship is attributed to the one-way marketing of live chickens from western regions to coastal regions of Tanzania. NDV could have spread from Tabora to Morogoro through live bird marketing, which is commonly practised (Mlozi et al. 2003). Therefore, live bird marketing may be the main vehicle for spreading ND in Tanzania.

Several amino acid sequence differences were detected in the studied isolates, specifically differences with regard to the fusion protein cleavage site. The differences correlated with virulence. Most results showed correlation between genotype F cleavage sequence and virulence for both slightly virulent and virulent NDV isolates. These results are in 
agreement with what was reported by Yu et al. (2001). Lack of correlation between ICPI values and the cleavage site motif, together with the findings on amino acid substitutions around the cleavage site, which leads to NDV with changed virulence, means that the actual virulence characteristics of an isolate cannot be determined by the cleavage site motif alone. Consequently, analysis of cleavage site motifs can be used only qualitatively to determine the virulence of NDV isolates. Therefore, the ICPI cannot be replaced in totality by analysis of the cleavage site. Furthermore, these results show that fusion protein gene cleavage site is not the only factor that determines virulence. Just as for the Avian influenza virus (Alexander 2000; Tollis \& Di Trani 2002) HN protein precursor also plays a role in the virulence of NDV (Cobaleda et al. 2002) and findings by Huang et al. (2003) show V protein of NDV significantly contribute to the virus virulence as an alpha/beta interferon antagonist. Thus, although F cleavage site is the major determinant of virulence, other factors also contribute to actual virus virulence.

Changes of NDV from avirulent to virulent was previously suspected from two outbreaks of ND amongst poultry in Ireland (Alexander et al. 1992). The causative NDV were velogenic and very similar, antigenically and genetically, to avirulent viruses isolated from feral waterfowls, suggesting that velogenic viruses arose from avirulent NDV from wild birds (Collins et al. 1993; Collins et al. 1998). Furthermore, recent outbreaks in Australia (1998-2001) revealed genetic resemblance of virulent NDV to field lentogenic isolates (Gould et al. 2001). In both field observations and the recent experimental study by Shengquing et al. (2002), step-by-step amino acid substitution was demonstrated. The management of FRCs allows for unlimited contact with other hosts including wild birds found to be infected mainly with lentogenic NDV, with the exception of few species (Takakuwa et al. 1998). This means that avirulent and lentogenic NDV isolates with avirulent genes have the potential to become velogenic after transmission to and repeated passage in chickens. Exposure to NDV and repeated passage are highest in FRCs compared to commercial chickens. Therefore, control of ND in FRC populations is important to reduce the chances of generating unselected populations of different NDV.

The presence of isolates in FRCs with drifting virulence suggests that virulent isolates could emerge from lentogenic vaccine viruses. These results have important implications for the use of live virus vaccine in the control of ND amongst rural FRCs as well as commercial chickens. Although there are no reports of cases of virulent NDV arising from the current live vaccines, future plans about ND control should take the possibility into consideration, especially with regard to ND control in rural FRC populations. It is recommended that old and new vaccines should be carefully selected and, when introduced, monitored to detect their conversion to virulence.

\section{Conclusion}

In conclusion, investigation of NDV isolated from FRCs in Tanzania showed presence of lentogenic, mesogenic and velogenic types, which phylogenetic analysis of a partial region of the fusion protein gene allocated to genotypes 1 , 2, 3c and 4a. Genotype 3c also included published sequences of Tanzanian isolates obtained from exotic birds and chicken isolates from Uganda. The analysis showed that NDV were persistently present among chicken populations and possibly spread through live chicken markets or migration of wild birds.

\section{References}

Abolnik, C., Horner, R.F., Bisschop, S.P., Parker, M.E., Romito, M. \& Viljoen, G.J.A., 2004, 'A phylogenetic study of South African Newcastle disease virus strains isolated between 1990 and 2002 suggests epidemiological origins in the Far East', Archives of Virology 49, 603-619. doi:10.1007/s00705-003-0218-2, PMid:14991446

Aldous, E.W. \& Alexander, D.J., 2001, 'Detection and differentiation of Newcastle disease virus (avian paramyxovirus type 1)', Avian Pathology 30, 117-128. doi:10.1080/03079450120044515, PMid:19184885

Aldous, E.W., Mynn, J.K., Banks, J. \& Alexander, D.J., 2003, 'A molecular epidemiological study of avian paramyxovirus type 1 (Newcastle disease virus) isolates by phylogenetic analysis of a partial nucleotide sequence of the fusion protein gene, Avian Pathology 32, 239-256. doi:10.1080/030794503100009783, doi:10.1080/0 307945031000097831, PMid:12850913

Alexander, D.J., 2000, 'A review of avian influenza in different bird species', Veterinary Microbiology 74, 3-13. doi:10.1016/S0378-1135(00)00160-7

Alexander, D.J., 2001, 'Gordon Memorial Lecture: Newcastle Disease', British Poultry Science 42, 5-22. doi:10.1080/713655022, PMid:11337967

Alexander, D.J., Campbell, G., Manvell, R.J., Collins, M.S., Parsons, G. \& McNulty, M.S., 1992, 'Characterisation of an antigenically unusual virus responsible for two outbreaks of Newcastle disease in the Republic of Ireland in 1990', Veterinary Records 130, 65-68. doi:10.1136/vr.130.4.65, PMid:1532467

Altschul, S.F., Madden, T.L., Schaffer, A.A., Zhang, J., Zhang, Z., Miller, W. et al., 1997, 'Gapped BLAST and PSI-BLAST: a new generation of protein database search programs', Nucleic Acids Research 25, 3389-3402. doi:10.1093/nar/25.17.3389, PMid:9254694, PMCid:146917

Ballagi-Pordány, A., Wehman, E., Herczeg, J., Belák, S. \& Lomniczi, B., 1996 'Identification and grouping of Newcastle disease virus strains by restriction site analysis of a region from the F gene', Archives of Virology 141, 243-261. doi:10.1007/BF01718397

Benson, D.A., Karsch-Mizrachi, I., Lipman, D.J., Ostell, J. \& Wheeler, D.L., 2004, 'GenBank: update', Nucleic Acids Research 32, D23-D26. doi:10.1093/nar/ gkh045, PMid:14681350, PMCid:308779

Commission of the European Communities (CEC). European Commission. 1992 'Legislation Governing: I The Control and Eradication of Newcastle Disease and Avian Influenza. II Trade in Poultry, Poultry Meat and Hatching Eggs'. In: European Commission Directorate General VI. Agriculture. Council Directive 92/66/EEC of 14 July 1992, Official Journal of the European Communities 5, L 260/1-L 260/20, viewed n.d., from http://europa.eu/legislation_summaries/food_safety/animal_ health/I12021 en.htm

Cobaleda, C., Munoz-Barroso, I., Sagrera, A. \& Villar, E., 2002, 'Fusogenic activity of reconstituted Newcastle disease virus envelope: a role for the haemagglutinin neuraminidase protein in the fusion process', International Journal of Biochemistry and Cell Biology 34, 403-413. doi:10.1016/S1357-2725(01)00127-3

Collins, M.S., Bashiruddin, J.B. \& Alexander, D.J., 1993, 'Deduced amino acid sequences at the fusion protein cleavage site of Newcastle disease viruses showing variations in antigenicity and pathogenicity', Archives of Virology 128 363-370. doi:10.1007/BF01309446, PMid:8435046

Collins, M.S., Franklin, S., Strong, I., Meulemans, G. \& Alexander, D.J., 1998, 'Antigenic and phylogenetic studies on a variant Newcastle disease virus using anti-fusion protein monoclonal antibodies and partial sequencing of the fusion protein gene' Avian Pathology 27, 90-96. doi:10.1080/03079459808419279, PMid:18483969

Collins, M.S., Govey, S.J. \& Alexander, D.J., 2003, 'Rapid in vitro assessment of the virulence of Newcastle disease virus isolates using the ligase chain reaction', Archives of Virology 148, 1851-1862. doi:10.1007/s00705-003-0131-8, PMid:14505095

Foster, H.A., Chitukuro, H.R., Tuppa, E., Mwanjala, T. \& Kusila, C., 1999, 'Thermostable Newcastle disease vaccines in Tanzania', Veterinary Microbiology 68, 127-130. doi:10.1016/S0378-1135(99)00068-1

Gould, A.R., Kattenbelt, J.A., Selleck, P., Hansson, E., Della-Porta, A. \& Westbury, H.A., 2001, 'Virulent Newcastle disease in Australia: Molecular epidemiology analysis of viruses isolated prior to and during the outbreaks of 1998-2000', Virus Research 77, 51-60. doi:10.1016/S0168-1702(01)00265-9

Gould, A.R., Hansson, E., Selleck, K., Kattenbelt, J.A., MacKenzie, M. \& Della-Porta, A.J., 2003, 'Newcastle disease virus fusion and haemagglutinin-neuraminidase gene motifs as markers for viral lineage', Avian Pathology 32, 361-373. doi:10.10 gene motifs as markers for viral lineage', Avian
80/0307945031000121112, PMid:17585460

Herczeg, J., Wehmann, E., Bragg, R.R., Travassos Dias, P.M., Hadjiev, G., Werner, $\mathrm{O}$. et al., 1999, 'Two novel genetic groups (VIIb and VIII) responsible for recent Newcastle disease outbreaks in Southern Africa, one (VIIb) of which recent Newcastle disease outbreaks in Southern Africa, one (VIllb) of which
reached Southern Europe', Archives of Virology 144, 2087-2099. doi:10.1007/ s007050050624, PMid:10603164 
Huang, Z., Krishhamurthy, S., Panda, A. \& Samal, S., 2003, 'Newcastle disease virus V protein is associated with viral pathogenesis and functions as an alpha interferon protein is associated with viral pathogenesis and functions as an alpha interferon antagonist', Journal of Virology 77, 8676-8
8685.2003, PMid:12885886, PMCid:167241

Jørgensen, P.H., Handberg, K.J., Ahrens, P., Hansen, H.C., Manwell, R.J. \& Alexander, D.J., 1999, 'An outbreak of Newcastle disease in free-living pheasants (Phasianus colchicus)', Journal of Veterinary Medicine B 46, 381-387. doi:10.1046/j.14390450.1999.00243.x

Kant, A., Koch, G., Van Roozelaar, D.J., Balk, F. \& Huurne, A.T., 1997, 'Differentiation of virulent and non-virulent strains of Newcastle disease virus within 24 hours by polymerase chain reaction', Avian Pathology 26, 837-849. doi:10.1080/03079459708419257, PMid:18483949

King, D.J. \& Seal, B.S., 1998, 'Biological and molecular characterization of Newcastle disease virus (NDV) field isolates with comparisons to reference NDV strains', Avian Diseases 37, 961-969. doi:10.2307/1591900, PMid:8141755

Li, Z., Nestor, K.E., Saif, Y.M., Anderson, J.W. \& Patterson, R.A., 2001, 'Effect of selection for increased body weight in turkeys on lymphoid organ weights, phagocytosis, and antibody responses to fowl cholera and Newcastle disease-inactivated vaccines', Poultry Science 80, 689-694.

Liang, R., Cao, D.J., Li, J.Q., Chen, J., Guo, X., Zhuang, F.F. \& Duan, M.X., 2002, 'Newcastle disease outbreaks in western China were caused by the genotypes VIla and VIII', Veterinary Microbiology 87, 193-203. doi:10.1016/S0378-1135(02)00050-0

Lomniczi, B., Wehmann, E., Herczeg, J., Ballagi-Pordány, A., Kaleta, E.F., Werner, O. et al., 1998, 'Newcastle disease outbreaks in recent years in Western Europe were caused by an old (VI) and a novel genotype (VII)', Archives of Virology 143, 49-64. doi:10.1007/s007050050267, PMid:9505965

Mlozi, M.R.S., Kakengi, A.M.V., Minga, U.M., Mtambo, A.M. \& Olsen, J.E., 2003, 'Marketing of free-range local chicken in Morogoro and Kilosa urban markets, Tanzania', Livestock Research for Rural Development 15(2), viewed 28 May 2011 from http://ftp.sunet.se/wmirror/www.cipav.org.co//rrd//rrd15/2/mloz152.htm.

Oberdörfer, A. \& Werner, O., 1998, 'Newcastle disease virus: detection and characterisation by PCR of recent German isolates differing in pathogenicity',
Avian Pathology 27, 237-243. doi:10.1080/03079459808419330, PMid:18483993

Office International des Epizooties (OIE), 2009, 'Newcastle disease', in Manual of Standards for Diagnostic Tests and Vaccines, 4th edn., viewed 28 May 2011, from $\mathrm{http} / / /$ www.oie.int/fileadmin/Home/eng/Animal_Health in the World/docs/ pdf/NEWCASTLE_DISEASE_FINAL.pdf

OIE. See Office International de Epizooties.

Otim, M.O., Christensen, H., Jørgensen, P.H., Handberg, K.J. \& Bisgaard, M., 2004 'Molecular characterization and phylogenetic study of Newcastle disease virus isolates from recent outbreaks in Eastern Uganda', Journal of Clinical Microbiolog 42, 2802-2805. doi:10.1128/JCM.42.6.2802-2805.2004, PMid:15184476, PMCid:427882

Peeters, B.P.H., De Leeuw, O.S., Koch, G. \& Gielkens, A.L., 1999, 'Rescue of Newcastle disease virus from cloned cDNA: evidence that cleavability of the fusion protein is a major determinant for virulence', Journal of Virology 73, 5001-5009. PMid:10233962, PMCid:112544

Permin, A. \& Hansen, J.W., 1998, 'Epidemiology, diagnosis and control of poultry parasites', in FAO Animal Health Manuals 4. FAO, Rome.

Phillips, R.J., Samson, A.C.R. \& Emmerson, P.T., 1998, 'Nucleotide sequence of the 5 - terminus of Newcastle disease virus and assembly of the complete genomic sequence: agreement with the "rule of six"', Archives of Virology 143, 1993-2002. doi:10.1007/s007050050435, PMid:9856086

Regmi, A., 2001, 'Changing structure of global food consumption and trade', Economic Research Service, US Department of Agriculture and Trade, Economic Research Service, Washington DC.

Sagild, I.K. \& Haresnape, J.M., 1987, 'The status of Newcastle disease and the use of V4 Vaccine in Malawi', Avian Pathology 16, 165-176. doi:10.1080/03079458708436361, PMid:18766600

Seal, B.S., King, D.J. \& Bennett, J.D., 1995, 'Characterization of Newcastle disease virus isolates by reverse transcription PCR coupled to direct nucleotide sequencing and development of sequence database for pathotype prediction and molecular epidemiological analysis', Journal of Clinical Microbiology 33, 2624-2630. PMid:8567895, PMCid:228544
Seal, B.S., King, D.J., Locke, D.P., Senne, D.A. \& Jackwood, M.W., 1998, 'Phylogenetic relationships among highly virulent Newcastle disease virus isolates obtained relationships among highly virulent Newcastle disease virus isolates obtained
from exotic birds and poultry from 1989 to 1996', Journal of Clinical Microbiology 36, 1141-1145. PMid:9542957, PMCid:104709

Sears, L.E., Moran, L.S., Kissinger, C., Creasey, T., Perry-O'Keefe, H., Roskey, M. et al., 1992, 'CircumVent thermal cycle sequencing and alternative manual and automated DNA sequencing protocols using the highly thermostable VentR (exo-) DNA polymerase', Biotechniques 13, 626-633. PMid:1476733

Shengquing, Y., Kishida, N., Ito, H., Kida, H., Otsuki, K., Kawaoka, Y. et al., 2002, 'Generation of Velogenic Newcastle disease viruses from non-pathogenic waterfowl isolates by passaging in chickens', Virology 301, 206-211. doi:10.1006/ viro.2002.1539, PMid:12359423

Snoeck, C.J., Ducatez, M.F., Owoade, A.A., Faleke, O.O., Alakli, B.R., Tahita, M.C. et al., 2009, 'Newcastle disease virus in West Africa: new virulent strains identified in non-commercial farms', Archives of Virology 154, 47-54. doi:10.1007/s00705008-0269-5, PMid:19052688

Spradbrow, P.B., 1993, 'Newcastle disease in village chickens', Poultry Science Reviews 5, 57-96.

Spradbrow, P.B., 2000, 'The Epidemiology of Newcastle Disease in Village Chickens', in R.G. Alders \& P.B. Spradbrow, SADC Planning Workshop on Newcastle disease control in village chickens: Maputo, Mozambique, March 6-9, 2000, p. 53-55.

Tamura, K., Dudley, J., Nei, M. \& Kumar, S., 2007, 'MEGA4: molecular evolutionary Genetics analysis (MEGA) software version 4.0', Molecular Biology and Evolution 24, 1596-1599. doi:10.1093/molbev/msm092, PMid:17488738

Takakuwa, H., Ito, T., Takada, A., Okazaki, K. \& Kida, H., 1998, 'Potentially virulent Newcastle disease viruses are maintained in migratory waterfowl populations', Japanese Journal of Veterinary Research 45, 207-215. PMid:9553325

Thompson, J.D., Gibson, T.J., Plewniak, F., Jeanmougin, F. \& Higging, D.G., 1997, 'The CLUSTAL_X Windows interface: flexible strategies for multiple sequence alignment aided by quality analysis tools', Nucleic Acids Research 25, 4876-4882. doi:10.1093/nar/25.24.4876, PMid:9396791, PMCid:147148

Tollis, M. \& Di Trani, L., 2002, 'Review: Recent development in avian influenza research: Epidemiology and immunoprophylaxis', Veterinary Journal 164, 202-215. doi:10.1053/tvjl.2002.0716, PMid:12505393

Tsai, C., Pan, C., Liu, M., Lin, Y., Chen, C., Huang, T. et al., 2000, 'Molecular epidemiological studies on Foot-and-Mouth disease type $O$ Taiwan viruses from 1997 epidemic', Veterinary Microbiology 74, 207-216. doi:10.1016/S03781135(00)00182-6

Van Regenmortel, M.H.V., Fauquet, C.M., Bishop, D.H.L., Carstens, E.B., Estes, M.K., Lemon, S.M. et al. (eds), 2000, 'Virus Taxonomy. Classification and Nomenclature of Viruses', in 7th Report of the International Committee on Taxonomy of Viruses, International Union of Microbiological Societies, Academic Press, London.

Wehmann, E., Czeglédi, A., Werner, O., Kaleta, E.F. \& Lomniczi, B., 2003, 'Occurrence of genotypes IV, V, VI and VIla in Newcastle disease outbreaks in Germany between 1939 and 1995', Avian Pathology 32, 157-163. doi:10.1080/03079450 21000071623, PMid:12745369

Westbury, H., 2001, 'Newcastle disease virus: an evolving pathogen?', Avian Pathology 30, 5-11. PMid:19184867

Yang, C.Y., Shieh, H.K., Lin, Y.L. \& Chang, P.C., 1999, 'Newcastle disease virus isolated from recent outbreaks in Taiwan phylogenetically related to viruses (genotype VII) from recent outbreaks in Western Europe', Avian Diseases 43, 125-130. doi:10.2307/1592771, PMid:10216769

Yongolo, M.G.S., 1996, 'Epidemiology of Newcastle disease in village chickens in Tanzania', MVM Dissertation, Department of Veterinary Microbiology and Parasitology, Sokoine University of Agriculture.

Yongolo, M.G.S., Machangu, A.M. \& Minga, U.M., 2002, 'Newcastle disease and Infectious bursal disease among free range village chickens in Tanzania', in Characteristics and parameters of family poultry production in Africa., IAEA, Vienna p. 107-116, viewed 28 May 2011, from http://www-naweb.iaea.org/ nafa/aph/public/aph-poultry-africa.html

Yu, L., Wang, Z., Jinng, Y., Chang, L. \& Kwang, J., 2001, 'Characterisation of newly emerging Newcastle disease virus isolates from the People's republic of Chin and Taiwan', Journal of Clinical Microbiology 39, 3512-3519. doi:10.1128/ JCM.39.10.3512-3519.2001, PMid:11574565, PMCid:88381 